\title{
Exploring the Artistic Image of Baby Suggs in Beloved
}

\author{
Liu Qingxiang
}

School of Humanities and Social Sciences, Heilongjiang Bayi Agricultural University, Heilongjiang, Daqing, Longfeng District, Xinyang Rd, China

DOI: $10.36347 /$ sjahss.2020.v08i05.006

| Received: 15.05 .2020 | Accepted: 26.05.2020 | Published: 30.05 .2020

*Corresponding author: Liu Qingxiang

Abstract

Regarding the vivid depiction of Baby Suggs, Toni Morrison fully exposed the numerous and monstrous crimes caused by slavery and the tragic fate of black slaves. The marvellous novelist spoke highly of the power, values and beliefs of black women, weaving dreams and myths, and modeling the enduring shape of black female slaves.

Keywords: Archetypal criticism; Beloved; Baby Suggs.

Copyright @ 2020: This is an open-access article distributed under the terms of the Creative Commons Attribution license which permits unrestricted use, distribution, and reproduction in any medium for non-commercial use (NonCommercial, or CC-BY-NC) provided the original author and source are credited.

\section{INTRODUCTION}

Beloved 1987(Pulitzer Prize for Fiction) is the masterpiece of Toni Morrison, a contemporary black American woman writer. The novel relates a story of infanticide and its aftermath to reveal the endless harm caused by criminal slavery, exploring the psychological trauma has a very great influence on the real world, especially black women during the history of black slavery. It portrays the images of the three generations of black women: Sethe, Baby Suggs, Danfu and Beloved. Most of the previous studies focused on the theme of the story, narrative aspects, the use of rhetorical devices, and the character of the heroines (Sethe and Beloved), while ignoring the black representative of the spirit of self-help, Baby Suggs. Morrison once said that the Bible was not part of her reading, but part of her life. This paper dwells on three muti-dimensional aspect of archetypal theory, religion and race to develop the psychological exploration of Baby Suggs, an American black woman, from slavery to "free" woman.

\section{Baby Suggs, the archetype of Jacob}

Northrop Frye, the first scholar who consciously applied the theory of "Archetype" to the field of literary research, believed that Generally speaking, literature is a myth of displacement, as well as only a continuation of myth [1]. And he sees literature as a reconstructed mythology, with its structural principles derived from those of myth.

Regarding myth as the core, African American literature focuses on the emancipation of slavery and the struggle of the Jews led by the Hebrew prophet Moses to get rid of slavery in Egypt, which is to some extent the key to understand African American literature [2]. Beloved is the scene of Exodus. Morrison gave her characters Biblical names in order to make people connect with their familiar biblical ones. As a result, many of the characters in Beloved not only have their own personal history described in the novel, but also have the history of those of the same name in the Bible. By naming his characters after the Bible, Morrison compares their experiences to those of epic heroes who transcend cultural and temporal boundaries. Sethe, the name of Seth, is a parody of the third child of Adam in the Bible, which means "replacing Abel". It's a kind-hearted parody and a parody of Seth, the embodiment of evil, hoping to get more favor from God. At the same time, sweet home, Beloved and four horsemen, under the catalysis of imitation, also constitute a joke and irony targeting at the Bible [3]. The following is a comparison between Baby Suggs and Jacob to reveal the setting of the characters.

Baby Suggs limped like a dog with only three legs due to a fall, while Jacob also fell down after wrestling with God and left a broken hip (Genesis 32). Likewise, they all changed their names. Before Baby Suggs was freed, the owners of "sweet house" called her 'Jenny', but after freedom, Baby Suggs had a sense of subjectivity, hated slavery very much and refused to accept the name. She insisted on naming herself after the man she once loved called her "Baby." "you (Jacob) have to change your name to Israel (he who wrestled with God), because you win the contest with God , people as well." According to the Bible, Jacob once saw a ladder in his sleep. The ladder grew up to heaven from the ground, and the angels relied on it, climbing up and down. So Jacob called his dream place "the home of 
God" and the gate of heaven, and vowed to build an altar there. Similarly, the free Baby lived in a two-story building, which provided clothes, goods and tools for black fugitives. In Bible and novel, the ladder or the stair symbolizes the connection between heaven and earth. Obviously, the image of ladders and stairs leading to a higher level of the world is widespread, at least in part because human beings can't fly, so they regard that climbing as the simplest metaphor that can make them ascend to heaven both physically and emotionally [4].

Jacob worked for her family for 14 years to marry a beloved woman, and then he married and gave birth to a son. He had 12 sons in all, but his favorite son was Joseph, the eldest son of his concubine. Jealous brothers sold Joseph as a slave to others because Jacob had made a colorful coat for him. As a result, Jacob was reluctant to live longer and always recalled Joseph with a colorful coat. This biblical story explains Suggs' experience. She and her son are doomed to work hard, moreover, she had to suffer from the loss of her sons. Suggs gave birth to eight children. Because of the cruel slavery, seven children left her. She didn't even know how the children grew up, and she never had the chance or clue to help her find out what she was like. In the southern part of the United States during the period of slavery, the greatest value of the existence of black women was to become a tool for the slave owners to vent their desires and give birth. Every new Baby Suggs is a part of their newly added property for slave owners, and have no human rights at all, let alone any family relationship. And some slave owners will even deliberately sell these slaves when they are very young, so as to prevent the adverse impact of this parent-child relationship on the slave owner's rule. Hale, her only favorite child, redeemed her freedom for Baby Suggs by working at weekends. She was once again forced to separate from her children due to slavery, and she had to continue working for white people to make a living. The filial Hale redeems his mother, which also coincides with the biblical story "the Sabbath cures the lame". Morrison also repeatedly mentioned "colorful square quilt" and "Carnival colored quilt", suggesting Suggs had a good wish to reunite with his son.

\section{The philanthropic spirit of Baby Suggs}

According to Steiner, French literary theorist and historian, various elements of a work of art are playing a role. Taking a literary work as an example, the primary element is a person with remarkable character [5]. Baby, a shape of one generation of African Americans, has witnessed their own unique history, including African life before the foundation of the United States, the tragic death of countless people on the way to the United States, the shackles of slavery more unbearable than death, the liberation struggle after the civil war, the polarization between rich and poor after entering the city, and gradual integration into the mainstream process. It took almost a lifetime for Baby to discover her identity. Although this kind of self- awareness was quickly defeated by slavery, she has taken the first step to establish her own subjective consciousness for black women.

Baby Suggs has mysterious power and foresight. She is the spiritual leader of the black community. Her words and actions are always at the center. She always knows what should be done at the right time. She also gives ideas while sending messages, curing diseases, hiding fugitives, cooking, preaching, singing and dancing, as if it was her unique occupation. She protects the black people and tells them the most important thing .It is due to her good heart that she always prevents being insulted and attacked by white people. In fact, she wanted the black people to cherish themselves, with the hope to help those who fled or liberated her compatriots to find their lost selves by the way of her sermon, because self-esteem and selfcultivation can improve human nature, and the life without love is not "survival".

The descendants of Jacob, also known as Israel, are redeemed because he does good and competes with God for deserved good. For Baby Suggs, the arrival of her grandson, granddaughter and daughter-in-law Sethe undoubtedly confirms her redemption from the perspective of family inheritance. The dream of a whole family, that every black man in the slavery period desperately wanted, ignited the heart of Baby. What Morrison is trying to express, as Dickens said, is to create a savage, gorgeous, abstract, symbolic character, but not a strange but full of deep feelings. When Sethe escaped to Baby with all her wounds and almost broken spirit, she accepted and had passion for Sethe. She cleans Seth's body as Jesus did for the world; she plays the perfect role of a mother in the family and a carer of a black community. Washing the wounds is like a baptism, which means that her daughter-in-law has received the conditions of belief and gained new life. She used several pies and hens to make a dinner for 90 people, which is very similar to the story of Jesus using a cake and two fish to make the listeners eat. Baby's divergent love seems to move the heaven, and let her help the persecuted people around her, trying to urge the suffering black compatriots to rise from the ashes of the national tragedy, trying to find the meaning of eternal hope.

Baby is actually the spiritual pillar of that community. As her name implies, she is not an ordinary old woman, but the mother of the earth who can reproduce. She is a conflagration against slavery, encouraging black people to deny and abandon the discrimination and contempt imposed on them by white people. As an unincorporated missionary, she admonished her followers to love their bodies. Her sermon was similar to African religious songs and some biblical verses, aiming to show that God asked voters to pity their bodies. "You pulled me out of the womb, and you made me want to snuggle up next to my mother's 
breasts. My God, my mother's belly. (Psalms 22) the Lord is my shepherd, and I have nothing missing. /His staff and his staff are my comfort. (Psalm 23 of the Bible), these poems reflect the harmonious relationship between man and God. These plots also imply that the newly born and blessed child, Danfu, will bear the burden of saving the nation, which is confirmed by the ending. There is no doubt that Baby often tells Danfu, "she should listen to her body and love it." In the end, since Danfu's sense of responsibility, courage and confidence occupied her body and mind. She was brave enough to enter the community and seek help. Suggs still inspired the living for a long time even after her death, her soul still lived in the black community, and strongly exert influence on those black groups who had received her education. Finally, the community finally realized the collective power and helped Sethe come out of the past and start a new life.

\section{The racial position of Baby Suggs}

The renaming of Baby Suggs denotes the idea of ethnic politics and rebellion against slavery. She wants to forget the miserable situation of black people in the past, helping people to heal the pain of the past and start a new life. It is not only a metaphor for the low social status of black race in America, but also a metaphor for their yearning for freedom and their inner feelings. The artist also has a special temperament, which can grasp the essence of the era quickly, and feel the spiritual climate of the times more carefully and comprehensively than the average humanists. For example, if sadness is the characteristics of the times, "what he sees is often darker than what others see at that time [6]. Baby thinks that in this country, there is no house without the sadness of black ghosts. Black people, regardless of men and women, are arbitrarily manipulated by white people. Her eight children have six fathers, and their children are arbitrarily disposed of. In this world, there is no other misfortune except white people. The lines show that she hates white people more than Sethe. From the perspective of Baby, though Mr. Ghana always thinks of himself as a benefactor, full of benevolence, righteousness and morality, he doesn't care about the physiological and emotional needs of the male slaves at all, but also lets Hale work on the Sabbath to redeem the black mother, deeply exposing the inhuman aspects of slavery. The white people's good or evil behavior is completely arbitrary, accidental, even emotional. The black people have no choice but to accept their life and death. When a slave has the shackles of slave system, love becomes an emotional responsibility. He must only serve the master, and his body being regarded as a special physical space, is buried in the manor, house, livestock and other property of the planter. Free from slavery, a black man can believe that what he loves will not be taken away. However, even when a person gets rid of slavery, he has to suffer from trauma. Baby's hope that the black community would unite ended up with a futile "racist" behavior. After a big meal at the celebration, the whole town was secretly jealous that she had taken up all the blessings and honors. The tragedy happened because the black community didn't help the poor family, the tragedy occurred, and the collapse of Baby was inevitable.

Self-respect and self-love are essential for black racism. Under the background of white barbarism and ignorance, self- love is very necessary for the black. But when the objective conditions of black life improved, there was no white barbarism and ignorance. If we continue to promote black self-respect and selflove, it seems to become an outdated idea. But Baby still fought against the fate of humiliation. She had devoted herself to awakening the love of the black people who were taken away by the savage white people, but the Black didn't love themselves, let alone others, and didn't fulfill the promise of love. After many years of praying and working, Baby Suggs finally gave up her belief in God -- unable to stop the white people from persecuting the black people physically and mentally. She gave up fighting with God, which to a certain extent showed that slavery had hurt the black people's spirit deeply. The tragic death of her granddaughter and the unknown whereabouts of her eight children are all evidence of slavery, school teachers, and the evil law. As Pau declared, "the law is our teacher, but once we have faith, he becomes the supreme authority"; Baby Suggs reversed this order, she had faith first, but later, the law and the teacher shook her belief. Finally, she was ill on the bed, looking at the color with a frail breath, immersed in the pain of thinking about her son. Giving up the evangelical faith in her body can be used to imply that she fell into a superficial racial category; at the same time, it also shows that women can't fight against the powerful slavery by themselves through various mental and physical tribulations under the double oppression of race and gender.

\section{REFERENCES}

1. Northrop F. The language of Divinity: a continuation of biblical and literary studies [M], social sciences literature press, 2004:167170

2. Qiu Y. Methods and cases of literary criticism [M], Peking University Press, 2007:118

3. Luo Y. The imitation of Beloved's Bible story and its significance $[\mathrm{J}]$, Journal of Southwest University for nationalities, 2011, 4.

4. Chang Y. A brief history of American literature [M], Nankai University Press, 2000:474.

5. Jingzhi H. The course of western literary theory [M], Peking University Press, 2003:508.

6. Han X. On the self search of three generations of black women in Toni Morrison's Beloved [J], Journal of Shenyang Agricultural University, 2009; 11(5): 635-637. 